\title{
Abnormal Sulfate Metabolism in Vitamin D-deficient Rats
}

\author{
Isabelle Fernandes, ${ }^{*}$ Geeta Hampson, ${ }^{*}$ Xavier Cahours, ${ }^{\ddagger}$ Philippe Morin, ${ }^{\ddagger}$ Christiane Coureau, ${ }^{*}$ Sylviane Couette,${ }^{*}$ \\ Dominique Prie, ${ }^{\star}$ Jürg Biber, ${ }^{\S}$ Heini Murer, ${ }^{\S}$ Gérard Friedlander, ${ }^{\star}$ and Caroline Silve ${ }^{\star}$ \\ *Inserm U 426, Faculté Xavier Bichat and Université Paris VII, Paris, France; ${ }^{*}$ Institut de Chimie Organique et Analytique and URA \\ CNRS 499, Université d'Orléans, Orléans, France; and ${ }^{\S}$ Department of Physiology, University of Zürich, Zürich, Switzerland
}

\section{Abstract}

To explore the possibility that vitamin D status regulates sulfate homeostasis, plasma sulfate levels, renal sulfate excretion, and the expression of the renal $\mathrm{Na}-\mathrm{SO}_{4}$ cotransporter were evaluated in vitamin $D_{-}$-deficient $\left(D^{-} D^{-}\right)$rats and in $\mathrm{D}^{-} \mathrm{D}^{-}$rats rendered normocalcemic by either vitamin $\mathrm{D}$ or calcium/lactose supplementation. $\mathrm{D}^{-} \mathrm{D}^{-}$rats had significantly lower plasma sulfate levels than control animals $(0.93 \pm 0.01$ and $1.15 \pm 0.05 \mathrm{mM}$, respectively, $P<$ 0.05 ), and fractional sulfate renal excretion was approximately threefold higher comparing $\mathrm{D}^{-} \mathrm{D}^{-}$and control rats. A decrease in renal cortical brush border membrane $\mathrm{Na}-\mathrm{SO}_{4}$ cotransport activity, associated with a parallel decrease in both renal $\mathrm{Na}_{-} \mathrm{SO}_{4}$ cotransport protein and mRNA content (78 \pm 3 and $73 \pm 3 \%$ decreases, respectively, compared with control values), was also observed in $\mathrm{D}^{-} \mathrm{D}^{-}$rats. Vitamin $\mathrm{D}$ supplementation resulted in a return to normal of plasma sulfate, fractional sulfate excretion, and both renal $\mathrm{Na}-\mathrm{SO}_{4}$ cotransport mRNA and protein. In contrast, renal sulfate excretion and renal $\mathrm{Na}-\mathrm{SO}_{4}$ cotransport activity, protein abundance, and mRNA remained decreased in vitamin D-depleted rats fed a diet supplemented with lactose and calcium, despite that these rats were normocalcemic, and had significantly lower levels of parathyroid hormone and $25(\mathrm{OH})$ and $1,25(\mathrm{OH})_{2}$-vitamin D levels than the vitamin D-supplemented groups. These results demonstrate that vitamin D modulates renal $\mathrm{Na}-\mathrm{SO}_{4}$ sulfate cotransport and sulfate homeostasis. The ability of vitamin $\mathrm{D}$ status to regulate $\mathrm{Na}-\mathrm{SO}_{4}$ cotransport appears to be a direct effect, and is not mediated by the effects of vitamin $D$ on plasma calcium or parathyroid hormone levels. Because sulfate is required for synthesis of essential matrix components, abnormal sulfate metabolism in vitamin D-deficient animals may contribute to producing some of the abnormalities observed in rickets and osteomalacia. (J. Clin. Invest. 1997. 100:2196-2203.) Key words: vitamin $\mathrm{D}$ deficiency $\bullet \mathrm{Na}-\mathrm{SO}_{4}$ cotransporter $\bullet$ sulfate homeostasis $\bullet$ parathyroid hormone

Address correspondence to Caroline Silve, M.D., Ph.D., INSERM U 426, BP 416, 16 rue Henri Huchard, 75870, Paris cedex 18 France. Phone: 33-1-44-85-62-73; FAX: 33-1-42-28-15-64; E-mail: silve@bichat. inserm.fr G. Hampson's present address is Division of Chemical Pathology, St. Thomas' Hospital, London SE1 7EH, United Kingdom.

Received for publication 11 February 1997 and accepted in revised form 27 August 1997.

J. Clin. Invest.

(C) The American Society for Clinical Investigation, Inc. 0021-9738/97/11/2196/08 \$2.00

Volume 100, Number 9, November 1997, 2196-2203

http://www.jci.org

\section{Introduction}

Sulfate, the fourth most abundant anion in human plasma, is known to play an essential role in a variety of biochemical processes. Despite its potential importance, sulfate levels are almost never measured in clinical practice, little is known about the factors that regulate sulfate homeostasis in mammals, and the possible contribution of abnormalities in the regulation of sulfate metabolism to the pathogenesis of human diseases is largely unexplored (1).

Sulfated proteoglycans constitute the largest group of sulfoconjugates in mammals, and it is well established that these proteoglycans are required for the maintenance of normal structure and function of bone and cartilage $(2,3)$. Thus, it is reasonable to postulate that diseases affecting sulfate metabolism may be likely to result in abnormalities in cartilage and/or bone. In support of this hypothesis, genetic defects involving a sulfate transport protein (DTDST) ${ }^{1}$ have been shown recently to be responsible for three different types of osteochondrodysplasia, diastrophic dysplasia, type IB achondrogenesis, and type II atelosteogenesis (4-6). In these osteochondrodysplasias, undersulfation of cartilage proteoglycans is associated with abnormalities affecting the organization of collagen fibrils, the tinctorial properties of proteoglycans, and the number and morphology of chondrocytes. The severity of the phenotype appears to be correlated with the predicted effect of the mutations on the residual activity of the DTDST protein (6). Similarly, a defect in the conversion of adenosine $5^{\prime}$-phosphosulfate to $3^{\prime}$-phosphoadenosine $5^{\prime}$-phosphosulfate produces brachymorphism in mice, a disorder characterized by short stature and associated with the production of undersulfated proteoglycans (7).

Several considerations raise the possibility that certain of the skeletal abnormalities seen in vitamin D deficiency could result from abnormal sulfate metabolism. First, several pathological features seen in $1,25(\mathrm{OH})_{2} \mathrm{D}$ deficiency states are not easily explained solely by changes in calcium and phosphate metabolism. Thus, although hypocalcemia and hypophosphatemia easily account for the impairment in mineral deposition typical of rickets and osteomalacia (8), the disorganization of the chondrocyte columns seen in rachitic cartilage and the presence of abnormalities in the maturation of chondrocytes $(8,9)$ are more difficult to attribute to this mechanism. Furthermore, changes in the physical properties of proteoglycan aggregates in rachitic rat bone (10) and a reduction in sulfate fixation in the matrix of growth plate cartilage in vitamin D-deficient rats have also been reported (11), findings that are consistent with the presence of abnormalities of sulfate metabolism in $1,25(\mathrm{OH})_{2} \mathrm{D}$ deficiency. Finally, the intestine and kidney, two of the principal target organs for $1,25(\mathrm{OH})_{2} \mathrm{D}$ action,

1. Abbreviations used in this paper: BBM, brush border membrane; DTDST, sulfate transport protein. 
are also known to represent the two most important tissues implicated in the regulation of extracellular concentrations of inorganic sulfate (12). Nevertheless, no direct evidence for abnormalities in the circulating levels of sulfate in vitamin D-deficient animals has been reported.

The aim of this study was to investigate the effects of vitamin D status on sulfate homeostasis. In view of the striking reduction in extracellular sulfate levels observed in vitamin D-deficient animals, the mechanisms responsible were further investigated. First, the effect of vitamin D deficiency on renal sulfate excretion and expression of the recently described renal $\mathrm{Na}-\mathrm{SO}_{4}$ cotransporter (13) was evaluated. Second, we sought to determine whether vitamin D deficiency per se played a direct role in the regulation of sulfate homeostasis, or whether the calcium deficiency and/or elevated circulating PTH levels produced by vitamin D deficiency were causative factors in this model.

\section{Methods}

Animals and diet. The animals were divided into four groups as reported (14). Briefly, a group of rats maintained on standard laboratory chow containing $0.75 \%$ calcium, $0.66 \%$ phosphate, and 2,000 $\mathrm{IU} / \mathrm{kg}$ vitamin $\mathrm{D}$ for $6 \mathrm{wk}$ served as controls (control or $\mathrm{D}^{+} \mathrm{D}^{+}$group). The second group of rats was given a vitamin $\mathrm{D}$-deficient diet containing $0.4 \%$ calcium and $0.3 \%$ phosphate for $6 \mathrm{wk}$ (vitamin D-deficient or $\mathrm{D}^{-} \mathrm{D}^{-}$group). The animals in groups 3 and 4 also received the vitamin D-deficient diet for the first $5 \mathrm{wk}$. Subsequently, this diet was supplemented during the sixth week with either $2,000 \mathrm{IU} / \mathrm{kg}$ vitamin $\mathrm{D}$ (vitamin $\mathrm{D}$-supplemented or $\mathrm{D}^{-} \mathrm{D}^{+}$group) or $1.6 \%$ calcium and $20 \%$ lactose (calcium/lactose-supplemented or $\mathrm{D}^{-} \mathrm{Ca}^{+}$group). Vitamin D-deficient diets supplemented with high calcium and lactose have been used previously to maintain normocalcemia in vitamin D-deficient rats $(15,16)$. In all cases, protein was given in the form of casein, and the amount of inorganic sulfate in the diets was similar. Animals were killed at $6 \mathrm{wk}$ after being anesthetized by intraperito-

Table I. Biochemical Parameters in the Four Groups of Rats

\begin{tabular}{|c|c|c|c|c|}
\hline \multirow[b]{2}{*}{ Parameter } & \multicolumn{4}{|c|}{ Experimental group } \\
\hline & $\mathrm{D}^{+} \mathrm{D}^{+}$ & $\mathrm{D}^{-} \mathrm{D}^{-}$ & $\mathrm{D}^{-} \mathrm{D}^{+}$ & $\mathrm{D}^{-} \mathrm{Ca}^{+}$ \\
\hline & $n=10$ & $n=14$ & $n=12$ & $n=7$ \\
\hline $\begin{array}{l}\text { Total calcium } \\
(\mathrm{mM})\end{array}$ & $2.42 \pm 0.05^{*}$ & $1.06 \pm 0.04^{\ddagger}$ & $2.61 \pm 0.05$ & $2.51 \pm 0.04$ \\
\hline $\begin{array}{l}\text { Phosphate } \\
\text { (mM) }\end{array}$ & $1.80 \pm 0.06^{\S}$ & $2.35 \pm 0.07$ & $2.39 \pm 0.09$ & $0.33 \pm 0.03$ \\
\hline $\begin{array}{l}\text { Creatinine } \\
(\mu \mathrm{M})\end{array}$ & $51.0 \pm 1.5$ & $54.5 \pm 1.2$ & $51.1 \pm 0.8$ & $48.8 \pm 2.0$ \\
\hline $\begin{array}{r}25(\mathrm{OH}) \mathrm{D} \\
(\mathrm{ng} / \mathrm{ml})\end{array}$ & $5.4 \pm 1.2$ & $<1^{\mathbb{\pi}}$ & $4.7 \pm 1.1$ & $<1^{\text {I }}$ \\
\hline $\begin{array}{c}1,25(\mathrm{OH})_{2} \mathrm{D} \\
(\mathrm{pg} / \mathrm{ml})\end{array}$ & $85 \pm 8$ & $45 \pm 6^{\mathscr{T}}$ & $88 \pm 14$ & $51 \pm 8^{4}$ \\
\hline $\begin{array}{l}\text { PTH } \\
\quad(\mathrm{pg} / \mathrm{ml})\end{array}$ & $44 \pm 8$ & $595 \pm 88^{\ddagger}$ & $104 \pm 37$ & $15 \pm 3 * *$ \\
\hline
\end{tabular}

*All values are expressed as mean \pm SEM. The number of animals studied is as indicated except for creatinine ( $n=6$ for each group). ${ }^{\ddagger} P<0.05$ compared to the $\mathrm{D}^{+} \mathrm{D}^{+}, \mathrm{D}^{-} \mathrm{D}^{+}$, and $\mathrm{D}^{-} \mathrm{Ca}^{+}$groups. ${ }^{\S} P<0.05$ compared to the $\mathrm{D}^{-} \mathrm{D}^{-}, \mathrm{D}^{-} \mathrm{D}^{+}$, and $\mathrm{D}^{-} \mathrm{Ca}^{+}$groups. ${ }^{\|} P<0.05$ compared to the $\mathrm{D}^{-} \mathrm{D}^{-}$and $\mathrm{D}^{-} \mathrm{D}^{+}$groups. ${ }^{\pi} P<0.05$ compared to the $\mathrm{D}^{+} \mathrm{D}^{+}$and $\mathrm{D}^{-} \mathrm{D}^{+}$ groups. ${ }^{*} P<0.05$ compared to the $\mathrm{D}^{+} \mathrm{D}^{+}$and $\mathrm{D}^{-} \mathrm{D}^{+}$groups. neal injection of phenobarbital. Plasma biochemical parameters for the animals studied here have been reported previously (14) and are summarized in Table I. For the study of the renal Na-SO $\mathrm{S}_{4}$ cotransporter, the kidneys were rapidly excised, immersed in liquid nitrogen, and stored at $-80^{\circ} \mathrm{C}$.

Measurement of plasma sulfate by capillary electrophoresis. Inorganic plasma sulfate and phosphate concentrations were determined by capillary electrophoresis using a P/ACE 2100 apparatus (Beckman Instruments, Inc., Fullerton, CA) equipped with a UV detector and $254 \mathrm{~nm}$ filter (17-20). Absorbance was continuously monitored using a $20 \mathrm{~Hz}$ sampling rate with a 0.1 -s time constant, and the area under the peaks corresponding to the migration of sulfate, corrected for the elution rate, was determined.

For each experiment, standard curves relating sample concentration to corrected peak area were generated using at least six different concentrations of the standard solutions. Regression analysis demonstrated that these standard curves were linear over the range of concentrations studied $(0.05-1 \mathrm{mM})$ with correlation coefficients $>0.998$. Each plasma sample was analyzed at two dilutions $(1 / 4$ and $1 / 8)$ in pure bi-distilled water, and three aliquots ( $8 \mathrm{nl}$ each) of each dilution were assayed. For each aliquot, sulfate concentrations were determined by interpolation from the standard curve, and the six values were averaged.

RNA extraction. Total RNA from kidney was extracted as described (14) using the guanidinium thiocyanate/cesium chloride method. RNA concentrations were determined by absorbance at $260 \mathrm{~nm}$, and the integrity of the RNA species was evaluated by electrophoresis into $1 \%$ agarose gels containing ethidium bromide. RNA preparations were stored at $-80^{\circ} \mathrm{C}$ until analysis.

Probes and ribonuclease (RNase) protection assays. To produce a plasmid from which $\mathrm{Na}-\mathrm{SO}_{4}$ cotransporter riboprobe could be transcribed, cDNA from rat kidney was used as template to amplify by

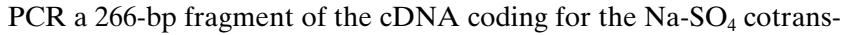
porter using the oligonucleotides 5'-GTAGCAAGGAAGCAGAATGT (upper primer) and 5'-ATTCACCCCCACCATCATCA (lower primer). The 266-bp fragment (corresponding to nucleotides 109-375 in the sequence published by Markovitch et al. [13]) was cloned into the pCR II vector (TA cloning kit; Invitrogen, San Diego, CA). The vector was linearized with SpeI and a 373-bp radiolabeled antisense RNA probe was generated by in vitro transcription using $\mathrm{T} 7$ polymerase and $\left.{ }^{32} \mathrm{P}\right] \mathrm{UTP}$. After hybridization with sample RNA and digestion with RNases, this riboprobe produced a specific protected fragment of $266 \mathrm{bp}$. A previously described construct containing a fragment of the cDNA coding for GAPDH cloned into Bluescript II $\mathrm{SK}^{+}$was used to synthesize a GAPDH riboprobe of $192 \mathrm{bp}$ that produced a specific protected fragment of $164 \mathrm{bp}$ in the RNase protection assay (14).

To perform the RNase protection assays, $10 \mu \mathrm{g}$ of total RNA extracted from the kidney of each animal was hybridized with $5 \times 10^{5}$ cpm Na-SO $\mathrm{S}_{4}$ riboprobe and $5 \times 10^{4} \mathrm{cpm}$ GAPDH riboprobe overnight at $50^{\circ} \mathrm{C}(14)$. The radioactivity present in the bands corresponding to the protected fragments of the $\mathrm{Na}_{-} \mathrm{SO}_{4}$ transporter and GAPDH riboprobes was quantified by electronic autoradiography (InstantImager; Packard Instruments, Meriden, CT). RNase protection analysis was performed in duplicate on samples from 6-10 animals in each group. For each sample, the $\mathrm{Na}_{-} \mathrm{SO}_{4}$ transporter mRNA/ GAPDH mRNA ratio was calculated. The results obtained in the control group $\left(\mathrm{D}^{+} \mathrm{D}^{+}\right)$were defined as $100 \%$, and the results from the three other groups of animals are expressed as a percentage of the value obtained for control animals studied in the same experiment.

Preparation of brush border membranes (BBM). BBM from kidney cortices were prepared by a $\mathrm{Mg}^{2+}$ precipitation method, as described (21). After the final centrifugation, BBM were resuspended in $10 \mathrm{mM}$ Tris- $\mathrm{HCl}$ ( $\mathrm{pH} 7.0)$ containing $50 \mathrm{mM}$ mannitol (Western blots), or $10 \mathrm{mM}$ Tris- $\mathrm{HCl}(\mathrm{pH} 7.5)$ containing $300 \mathrm{mM}$ mannitol $\left(\mathrm{Na}-\mathrm{SO}_{4}\right.$ transport measurements). Protein was measured using the Coomassie protein assay reagent (Pierce Chemical Co., Rockford, IL) based on the Bradford method (22). 
Preparation of antibodies. Polyclonal antibodies against renal $\mathrm{Na}-\mathrm{SO}_{4}$ cotransporter NaSi-1 (13) were raised in rabbits by immunization with a fusion protein containing a 53 -amino acid polypeptide derived from the $\mathrm{Na}_{-} \mathrm{SO}_{4}$ cotransporter sequence. This antibody preparation specifically detected a $68-\mathrm{kD}$ protein on Western blots of proteins isolated from renal BBM and specifically stained proximal tubular BBM in renal tissue evaluated using immunohistochemical techniques (23). A second nonspecific band of apparent molecular mass of $70 \mathrm{kD}$ was also detected with the antibody. As previously reported (23), the reactivity of the antibody with this band is not prevented in the presence of the antigenic fusion protein, and the expression of this band is not regulated.

$B B M$ protein electrophoresis and Western blots. Experiments were performed as described (24). Briefly, BBM proteins were denatured in $95 \mathrm{mM}$ Tris- $\mathrm{HCl}$ (pH 6.8) containing $2 \%$ SDS, $10 \%$ glycerol, $0.5 \mathrm{mM}$ EDTA, and $100 \mathrm{mM}$ dithiothreitol (final concentrations). $35 \mu \mathrm{g} \mathrm{BBM}$ protein per lane was electrophoresed on $10 \%$ polyacrylamide gels according to Laemmli (25), and the samples were electrotransferred onto nitrocellulose membranes. After blocking the membrane with Tris-buffered saline ( $\mathrm{pH} 7.4$ ) containing 5\% skimmed dried milk and $1 \%$ Triton X-100, membranes were incubated overnight with a 1:5,000

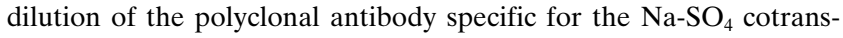
porter NaSi-1. Antibody binding was detected by chemiluminescence using the ECL Western blotting protocol (Amersham Life Science, Buckinghamshire, UK) as described by the manufacturer, using a donkey anti-rabbit whole antibody linked to horseradish peroxidase. Signals recorded on $\mathrm{x}$-ray film were quantified by densitometric scanning and peaks integrated using the Image Quant software package (Molecular Dynamics Inc., Sunnyvale, CA). Western blots were performed on BBM prepared from kidneys obtained from three rats in each group. Results are expressed relative to values obtained for the control rats $\left(\mathrm{D}^{+} \mathrm{D}^{+}\right.$group) studied in each series of experiments. Equal loading was ensured by protein staining of gels run in parallel.

BBM Na-SO $\mathrm{S}_{4}$ transport measurements. Measurement of $\mathrm{Na}^{-\mathrm{SO}_{4}}$ transport was performed on freshly isolated $\mathrm{BBM}$ vesicles using a procedure based on radioisotope uptake followed by rapid Millipore filtration, as described $(26,27)$. Suspensions of BBM were equilibrated at room temperature for $1 \mathrm{~h}$ in preloading buffer $(10 \mathrm{mM}$ Tris$\mathrm{HCl}, \mathrm{pH} 7.5$, containing $300 \mathrm{mM}$ mannitol). $30 \mu \mathrm{g}$ of BBM suspended in $10 \mu \mathrm{l}$ of preloading buffer was then mixed at room temperature with $40 \mu \mathrm{l}$ of extravesicular uptake buffer containing $50 \mu \mathrm{Ci} / \mathrm{ml}$ $\mathrm{H}_{2}\left[{ }^{35} \mathrm{~S}\right] \mathrm{SO}_{4}(43 \mathrm{Ci} / \mathrm{mg}$; ICN Biomedicals, Costa Mesa, CA) to produce solutions containing (final concentrations) $5 \mathrm{mM}$ Tris- $\mathrm{HCl}(\mathrm{pH} 7.5)$, $100 \mathrm{mM}$ mannitol, and either $100 \mathrm{mM}$ Na-gluconate (Na-dependent uptake) or $100 \mathrm{mM}$ potassium gluconate (Na-independent uptake) in the presence of $0.05-5 \mathrm{mM} \mathrm{K}_{2}\left[{ }^{35} \mathrm{~S}_{\mathrm{SO}_{4}}\right.$. Uptake was terminated after $90 \mathrm{~s}$ by the addition of $2 \mathrm{ml}$ of ice-cold stop solution (10 mM Tris$\mathrm{HCl}, \mathrm{pH} 7.5$, containing $300 \mathrm{mM}$ mannitol, $2 \mathrm{mM} \mathrm{CaCl}_{2}$, and $1 \mathrm{mM}$ $\mathrm{HgCl}_{2}$ ) (28) and filtration of the suspension across a $0.45-\mu \mathrm{m}$ pore membrane (HAWP; Millipore Corp., Milford, MA). Filters were then washed four additional times with $2 \mathrm{ml}$ stop solution, and radioactivity was counted. $\left[{ }^{35} \mathrm{~S}_{\mathrm{SO}} \mathrm{S}_{4}\right.$ specific activity was determined experimentally for each series of measurements. Na-dependent $\mathrm{SO}_{4}$ uptake was calculated by subtracting the uptake measured under $\mathrm{Na}^{+}$-free conditions from that observed in the presence of $\mathrm{Na}^{+}$at each $\mathrm{K}_{2} \mathrm{SO}_{4}$ concentration. Results are expressed as nanomoles of $\mathrm{SO}_{4}$ per $90 \mathrm{~s}$ per milligram of protein.

Urinary sulfate excretion. Urinary sulfate excretion was measured on nine vitamin-deficient rats (seven $\mathrm{D}^{-} \mathrm{D}^{-}$, two $\mathrm{D}^{-} \mathrm{Ca}^{+}$), and six vitamin $\mathrm{D}$-supplemented rats (four $\mathrm{D}^{+} \mathrm{D}^{+}$, two $\mathrm{D}^{-} \mathrm{D}^{+}$). Anesthesia, surgical preparation of the animals, and infusion of $\left[{ }^{3} \mathrm{H}\right]$ inulin were performed as previously described $(29,30) . \mathrm{H}_{2}\left[{ }^{35} \mathrm{~S}\right] \mathrm{SO}_{4}(43 \mathrm{Ci} / \mathrm{mg}$; ICN Biomedicals) was suspended in $0.15 \mathrm{M} \mathrm{NaCl}$ and administered by intravenous infusion at a rate of $50 \mu \mathrm{l} / \mathrm{min}$ per $100 \mathrm{~g}$ body wt until a total dose of $100 \mu \mathrm{Ci} / 200 \mathrm{~g}$ body wt had been administered. Inulin and sulfate clearances were measured as previously reported $(29,30)$.

Presentation of data and statistical analysis. Results are presented as mean \pm SEM unless otherwise stated. Samples from the different groups of rats were evaluated simultaneously in all experiments. Statistical comparisons were performed by one-way ANOVA; comparisons between individual groups were made using the Fisher LSD test (31). Fractional sulfate excretion was expressed as a function of urinary output, and results were analyzed by comparing the regression lines obtained for the vitamin D-supplemented and the vitamin-deficient rats (31). $P$ values $<0.05$ were considered significant.

\section{Results}

Effects of vitamin D deficiency and vitamin D supplementation on sulfate homeostasis

Inorganic plasma sulfate concentrations. The mean plasma sulfate concentration of vitamin $\mathrm{D}$-deficient rats $\left(\mathrm{D}^{-} \mathrm{D}^{-}\right.$group) was significantly lower than that of control rats $\left(\mathrm{D}^{+} \mathrm{D}^{+}\right.$group) (0.93 \pm 0.01 and $1.15 \pm 0.05 \mathrm{mM}$, respectively, $P<0.05)$. When vitamin $\mathrm{D}$-deficient animals received a diet containing vitamin D supplementation for $1 \mathrm{wk}$ before evaluation, however, plasma sulfate levels were similar to those of control animals (1.22 $\pm 0.03 \mathrm{mM}, P>0.2$ comparing the $\mathrm{D}^{-} \mathrm{D}^{+}$group and $\mathrm{D}^{+} \mathrm{D}^{+}$group).

$\mathrm{Na}-\mathrm{SO}_{4}$ cotransporter $m \mathrm{RNA}$ expression. Because renal reabsorption of sulfate is important in maintaining plasma sulfate levels within a normal range, abnormalities in the expression of the renal $\mathrm{Na}-\mathrm{SO}_{4}$ transporter represent a possible cause of hyposulfatemia seen in vitamin D-deficient rats. To explore this possibility, mRNA coding for the $\mathrm{Na}_{-} \mathrm{SO}_{4}$ cotransporter was measured in kidney from vitamin D-deficient and control animals using RNase protection analysis (Fig. 1). In all experiments, the amount of $\mathrm{Na}-\mathrm{SO}_{4}$ cotransporter mRNA in kidney from the vitamin $\mathrm{D}$-deficient rats $\left(\mathrm{D}^{-} \mathrm{D}^{-}\right.$group) was found to be reduced compared with that obtained in kidneys from control animals $\left(\mathrm{D}^{+} \mathrm{D}^{+}\right.$group). Overall, the ratio of counts per minute in the bands corresponding to the protected fragments of $\mathrm{Na}_{-} \mathrm{SO}_{4}$ cotransporter mRNA and GAPDH mRNA was reduced by $73 \pm 3 \%$ compared with vitamin $\mathrm{D}$-deficient and control animals (Fig. $1 B, P<0.05$ ). As was observed for plasma sulfate levels, $\mathrm{Na}-\mathrm{SO}_{4}$ cotransporter mRNA levels were normal in vitamin D-deficient animals that received vitamin D supplementation for $1 \mathrm{wk}$ before time of killing (95 $\pm 8 \%$ of control values, Fig. 1). Similar changes were not observed for $\mathrm{Na}-\mathrm{PO}_{4}$ cotransporter type II mRNA (32) as previously reported in similar experimental conditions (33) (data not shown).

$\mathrm{Na}-\mathrm{SO}_{4}$ cotransporter protein abundance. To determine whether the reduction in mRNA coding for the $\mathrm{Na}-\mathrm{SO}_{4}$ cotransporter seen in vitamin D-deficient animals was associated with reduced expression of the cotransporter protein, $\mathrm{BBM}$ were isolated from kidney cortex, and $\mathrm{Na}-\mathrm{SO}_{4}$ cotransporter protein was measured by Western blotting. Vitamin D deficiency was associated with a $78 \pm 3 \%$ decrease in the abundance of the $\mathrm{Na}_{-} \mathrm{SO}_{4}$ cotransport protein (Fig. 2, $P<0.05$ comparing vitamin D-deficient animals and controls). Strikingly, vitamin D supplementation of previously vitamin D-deficient animals for $1 \mathrm{wk}$ before time of killing led to an increase in $\mathrm{Na}$ $\mathrm{SO}_{4}$ cotransporter protein expression to levels similar to those observed in the control animals (Fig. 2, 78 $\pm 16 \%$ of control values, $P>0.2$ comparing animals in the $\mathrm{D}^{-} \mathrm{D}^{+}$and $\mathrm{D}^{+} \mathrm{D}^{+}$ groups). In contrast to $\mathrm{Na}-\mathrm{SO}_{4}$ cotransporter protein expression, no decrease in the $\mathrm{Na}-\mathrm{PO}_{4}$ cotransporter protein type II was seen when the same blots were probed with an antibody raised against a $\mathrm{NH}_{2}$-terminal peptide of the $\mathrm{Na}-\mathrm{PO}_{4}$ cotrans- 


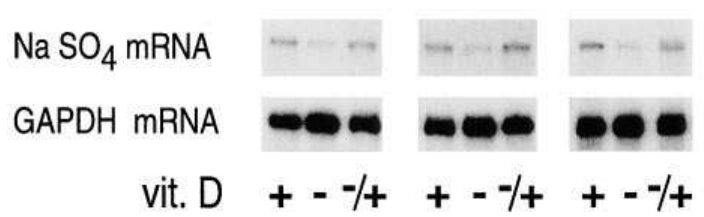

B

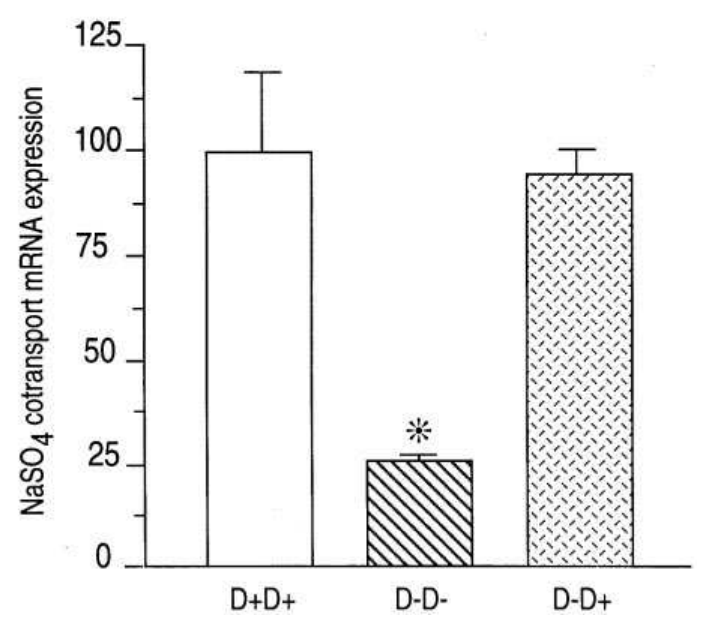

Figure 1. RNase protection analysis of $\mathrm{Na}-\mathrm{SO}_{4}$ cotransporter mRNA expression in kidney obtained from control $\left(\mathrm{D}^{+} \mathrm{D}^{+}\right)$, vitamin $\mathrm{D}-$ deficient $\left(\mathrm{D}^{-} \mathrm{D}^{-}\right)$, and vitamin $\mathrm{D}-$ supplemented $\left(\mathrm{D}^{-} \mathrm{D}^{+}\right)$rats. $(A) 10 \mu \mathrm{g}$ of total RNA from kidney of control $(+)$, vitamin D-deficient $(-)$, and vitamin $\mathrm{D}-$ supplemented $(-/+)$ rats was hybridized with radiolabeled riboprobes recognizing $\mathrm{Na}-\mathrm{SO}_{4}$ cotransporter and GAPDH mRNAs, incubated in the presence of RNases, and the protected fragments were separated by acrylamide gel electrophoresis. (A) Autoradiographs of the protected fragments from three different experiments $(1,2$, and 3$)$ are presented. (B) Quantification of $\mathrm{Na}^{-} \mathrm{SO}_{4}$ mRNA. Radioactivity (counts per minute) present in the bands corresponding to the protected fragments of $\mathrm{Na}_{-} \mathrm{SO}_{4}$ cotransporter and GAPDH riboprobes was determined by electronic autoradiography, and the ratio of the counts per minute for the $\mathrm{Na}-\mathrm{SO}_{4}$ cotransport mRNA band over the counts in the GAPDH mRNA band was calculated. Results for each animal were then expressed as a percentage of the average results obtained for control $\left(\mathrm{D}^{+} \mathrm{D}^{+}\right)$rats evaluated in the same experiment. Shown are the mean \pm SEM of results obtained for 8 animals in the $\mathrm{D}^{+} \mathrm{D}^{+}$group, and 10 animals in the $\mathrm{D}^{-} \mathrm{D}^{-}$and $\mathrm{D}^{-} \mathrm{D}^{+}$ groups. The result for one rat is the mean of two determinations. $* P<0.05$ compared with the $\mathrm{D}^{+} \mathrm{D}^{+}$and $\mathrm{D}^{-} \mathrm{D}^{+}$groups.

porter type II (data not shown). The presence of a decreased $\mathrm{Na}-\mathrm{SO}_{4}$ cotransporter in absence of a decreased $\mathrm{Na}-\mathrm{PO}_{4}$ cotransporter underlines the fact that the changes in $\mathrm{Na}-\mathrm{SO}_{4}$ cotransporter are not one of multiple impairments of sodiumcoupled cotransporters in renal proximal tubules.

$\mathrm{BBM} \mathrm{Na}-\mathrm{SO}_{4}$ cotransport activity. In agreement with the decrease in $\mathrm{Na}_{-} \mathrm{SO}_{4}$ cotransporter protein expression, vitamin $\mathrm{D}$ deficiency caused a significant decrease in $\mathrm{BBM} \mathrm{Na}-\mathrm{SO}_{4} \mathrm{Co}-$ transport activity (Fig. 3). Studies evaluating the kinetics of $\mathrm{Na}$-dependent $\mathrm{SO}_{4}$ cotransport as a function of extravesicular $\mathrm{SO}_{4}$ concentration indicated that vitamin $\mathrm{D}$ deprivation caused a decrease in the $V_{\max }$ of $\mathrm{Na}-\mathrm{SO}_{4}$ cotransport, without changing the affinity of the transporter for $\mathrm{SO}_{4}$ (Fig. 3, inset).
Effect of calcium supplementation on sulfate homeostasis in vitamin $D$-deficient rats

It was of interest to determine whether the hyposulfatemia and changes in renal $\mathrm{Na}-\mathrm{SO}_{4}$ cotransport as observed in vitamin D-deficient rats were a direct consequence of vitamin D deficiency, or whether secondary changes resulting from vitamin D deficiency, such as hypocalcemia and/or hyperparathyroidism, were more directly involved in producing the changes in sulfate metabolism. To evaluate this question, rats receiving a vitamin D-deficient diet that was supplemented with high calcium and lactose during the final week before time of killing were also studied. As expected, calcium/lactose supplementation $\left(\mathrm{D}^{-} \mathrm{Ca}^{+}\right.$group) produced an increase in plasma calcium to levels similar to those of control animals (Table I). Plasma PTH concentrations decreased substantially in these normocalcemic rats, whereas plasma $25(\mathrm{OH}) \mathrm{D}$ and $1,25(\mathrm{OH})_{2}$ concentrations remained significantly lower than those of control rats (Table I). As was observed for calcium concentrations, plasma sulfate concentrations in the rats receiving lactose/calcium supplementation also increased to levels that were not significantly different from those of control animals $(1.09 \pm 0.01$

A

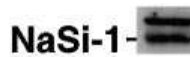

B

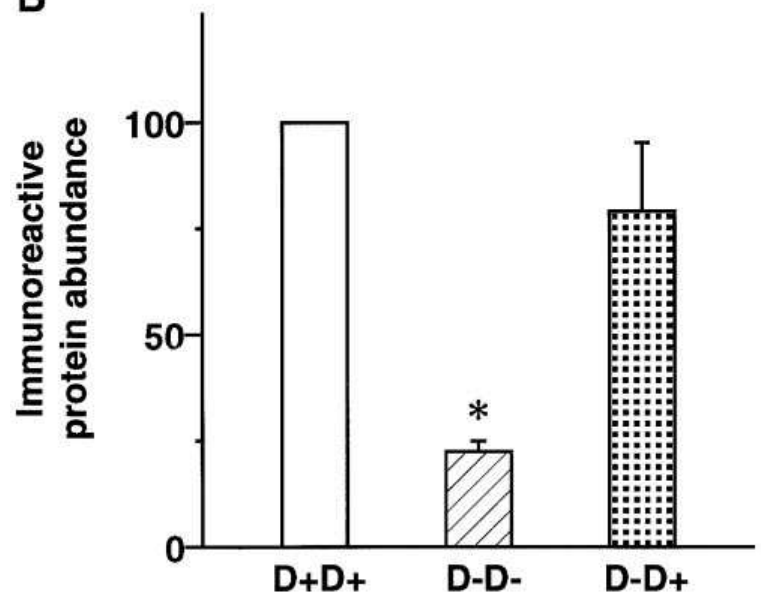

Figure 2. Immunoblotting of $\mathrm{Na}_{-} \mathrm{SO}_{4}$ cotransporter protein in BBM. $35 \mu \mathrm{g}$ of BBM protein freshly prepared from the renal cortices was separated by SDS-PAGE and transferred to nitrocellulose membranes as described in Methods. Blots were incubated sequentially with a polyclonal rabbit anti-Na-SO ${ }_{4}$ cotransporter ( $\left.\mathrm{NaSi}-1\right)$ antibody and a donkey anti-rabbit whole antibody linked to horseradish peroxidase, and antibody binding was detected by chemiluminescence using the ECL Western blotting protocol (Amersham Life Science). (A) Example of results obtained using BBM proteins prepared from kidneys of control $\left(\mathrm{D}^{+} \mathrm{D}^{+}\right)$, vitamin $\mathrm{D}$-deficient $\left(\mathrm{D}^{-} \mathrm{D}^{-}\right)$, and vitamin D-supplemented $\left(\mathrm{D}^{-} \mathrm{D}^{+}\right)$rats in one experiment. $(B)$ Quantification of $\mathrm{Na}_{-} \mathrm{SO}_{4}$ cotransporter protein expression. Bands corresponding to the Na-SO $\mathrm{S}_{4}$ cotransporter were quantitated by densitometry, and results are expressed as a percentage of the result obtained for the control $\left(\mathrm{D}^{+} \mathrm{D}^{+}\right)$rat evaluated in the same experiment. Shown are the mean \pm SEM for three experiments. $* P<0.05$ compared with the $\mathrm{D}^{+} \mathrm{D}^{+}$and $\mathrm{D}^{-} \mathrm{D}^{+}$groups. The upper band is a nonspecific band detected by the antibody, as described in Methods and reference 23. 


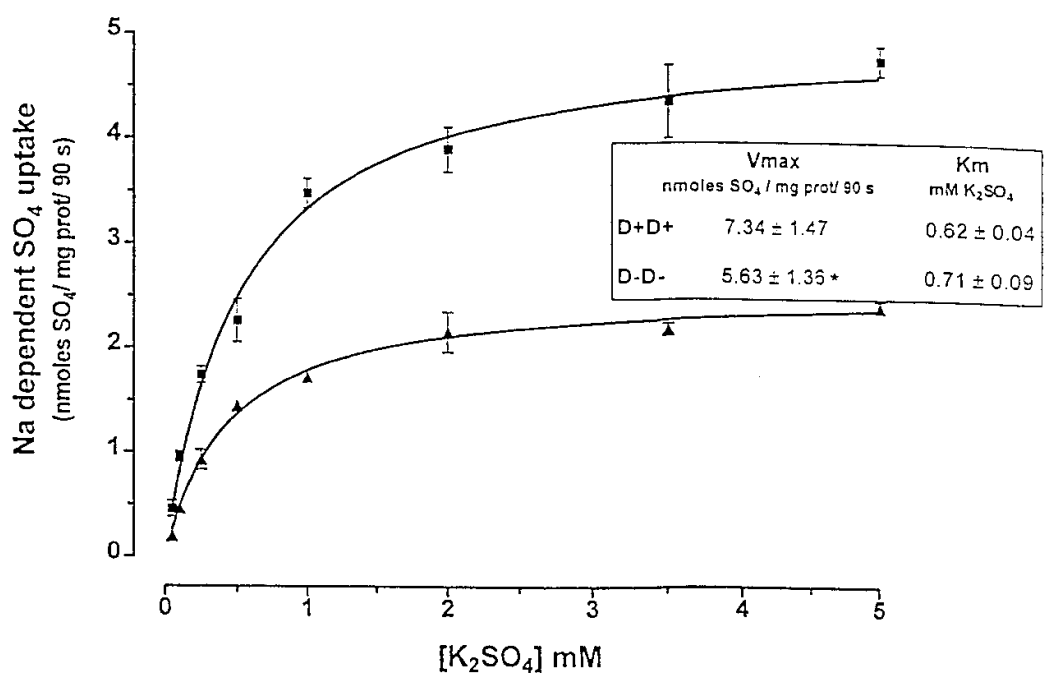

Figure 3. Effect of vitamin D deficiency on the kinetics of $\mathrm{Na}-\mathrm{SO}_{4}$ cotransport in BBM. Na-dependent $\mathrm{SO}_{4}{ }^{2-}$ uptake by BBM from control $\left(\mathrm{D}^{+} \mathrm{D}^{+}\right.$, squares $)$ and vitamin $\mathrm{D}-$ deficient rats $\left(\mathrm{D}^{-} \mathrm{D}^{-}\right.$, triangles $)$was measured as a function of the concentration of extravesicular sulfate, and is presented as nanomoles of $\mathrm{SO}_{4}{ }^{2-}$ per milligram of protein per $90 \mathrm{~s}$. Kinetic parameters were calculated by nonlinear curve fitting, assuming Michaelis-Menton kinetics, and the data (inset) are the mean \pm SEM obtained from the study of BBM preparations from kidneys obtained from five different rats in each group. For each point, uptake measurements were performed in triplicate. The graph presents representative results obtained for one rat from each group in a single experiment. Na-dependent $\mathrm{SO}_{4}$ uptake was calculated by subtracting the uptake measured under $\mathrm{Na}^{+}$-free conditions from that observed in the presence of $\mathrm{Na}^{+}$at each $\mathrm{K}_{2} \mathrm{SO}_{4}$ concentration. ${ }^{*} P<0.05$ compared with $\mathrm{D}^{+} \mathrm{D}^{+}$group. and $1.15 \pm 0.05 \mathrm{mM}$ in the $\mathrm{D}^{-} \mathrm{Ca}^{+}$and $\mathrm{D}^{+} \mathrm{D}^{+}$groups, respectively).

In contrast to the striking effect observed in response to vitamin D supplementation, however, treatment of vitamin D-deficient rats with calcium/lactose supplementation did not change renal Na-SO $\mathrm{S}_{4}$ cotransport. Thus, despite the normalization of plasma calcium and the marked decrease in plasma PTH levels observed in calcium/lactose-supplemented animals, renal $\mathrm{Na}-\mathrm{SO}_{4}$ cotransport steady state mRNA levels, protein abundance, and activity were reduced to a similar extent in the $\mathrm{D}^{-} \mathrm{D}^{-}$and $\mathrm{D}^{-} \mathrm{Ca}^{+}$groups compared with the control $\left(\mathrm{D}^{+} \mathrm{D}^{+}\right)$ group (Table II).

\section{Effect of vitamin D status on urinary sulfate excretion}

To directly evaluate whether the changes in renal $\mathrm{Na}-\mathrm{SO}_{4}$ cotransport activity observed in vitamin D-deficient animals resulted in changes in renal handling of sulfate, urinary sulfate

Table II. Effect of Calcium Supplementation on $\mathrm{Na}-\mathrm{SO}_{4}$ Cotransport mRNA Expression, Protein Abundance, and Activity in Vitamin D-deficient Rats

\begin{tabular}{|c|c|c|c|}
\hline \multirow[b]{2}{*}{ Parameter } & \multicolumn{3}{|c|}{ Experimental group } \\
\hline & $\mathrm{D}^{+} \mathrm{D}^{+}$ & $\mathrm{D}^{-} \mathrm{D}^{-}$ & $\mathrm{D}^{-} \mathrm{Ca}^{+}$ \\
\hline \multicolumn{4}{|l|}{ mRNA expression $* \ddagger$} \\
\hline (\% control) & $100 \pm 19$ & $27 \pm 3^{\S}$ & $30 \pm 2^{\S}$ \\
\hline \multicolumn{4}{|l|}{ Immunoreactive protein $* \|$} \\
\hline (\% control) & $100 \pm 3$ & $22 \pm 3^{\S}$ & $40 \pm 2^{\S}$ \\
\hline \multicolumn{4}{|l|}{$\mathrm{Na}-\mathrm{SO}_{4}$ cotransport activity ${ }^{\mathbb{I I}}$} \\
\hline$V_{\max }\left(\mathrm{nmol} \mathrm{SO} \mathrm{S}_{4} / \mathrm{mg}\right.$ protein $\left./ 90 \mathrm{~s}\right)$ & $7.34 \pm 1.47$ & $5.63 \pm 1.36^{\S}$ & $4.11 \pm 0.81^{\S}$ \\
\hline$K_{\mathrm{m}}\left(\mathrm{mM} \mathrm{SO}_{4}\right)$ & $0.62 \pm 0.04$ & $0.71 \pm 0.09$ & $0.76 \pm 0.12$ \\
\hline
\end{tabular}

All results are the mean \pm SEM. * Results are expressed as the percentage of the average value obtained for the control $\left(\mathrm{D}^{+} \mathrm{D}^{+}\right)$animals evaluated in each experiment. ${ }^{*}$ Experiments were performed in duplicate on samples from $8\left(\mathrm{D}^{+} \mathrm{D}^{+}\right.$group $), 10\left(\mathrm{D}^{-} \mathrm{D}^{-}\right.$group $)$, and $6\left(\mathrm{D}^{-} \mathrm{Ca}^{+}\right.$ group) animals. ${ }^{\S} P<0.05$ compared to $\mathrm{D}^{+} \mathrm{D}^{+}$group. $\|_{n}=3$ for all groups. "Experiments were performed in triplicate on kidneys from five different rats in each group. excretion in vivo was evaluated in vitamin D-deficient and control rats. Glomerular filtration rates were not significantly modified by vitamin D status $(0.48 \pm 0.04$ vs. $0.58 \pm 0.09 \mathrm{ml} / \mathrm{min}$ per $100 \mathrm{~g}$ of body wt, mean \pm SEM, respectively, in vitamin D-depleted $[n=9]$ and vitamin D-repleted $[n=6]$ rats, $P>$ 0.2). As shown in Fig. 4, the fractional excretion of sulfate in these animals varied as a function of urinary output. Importantly, for any given level of urinary output, fractional sulfate excretion was approximately threefold higher comparing vita-

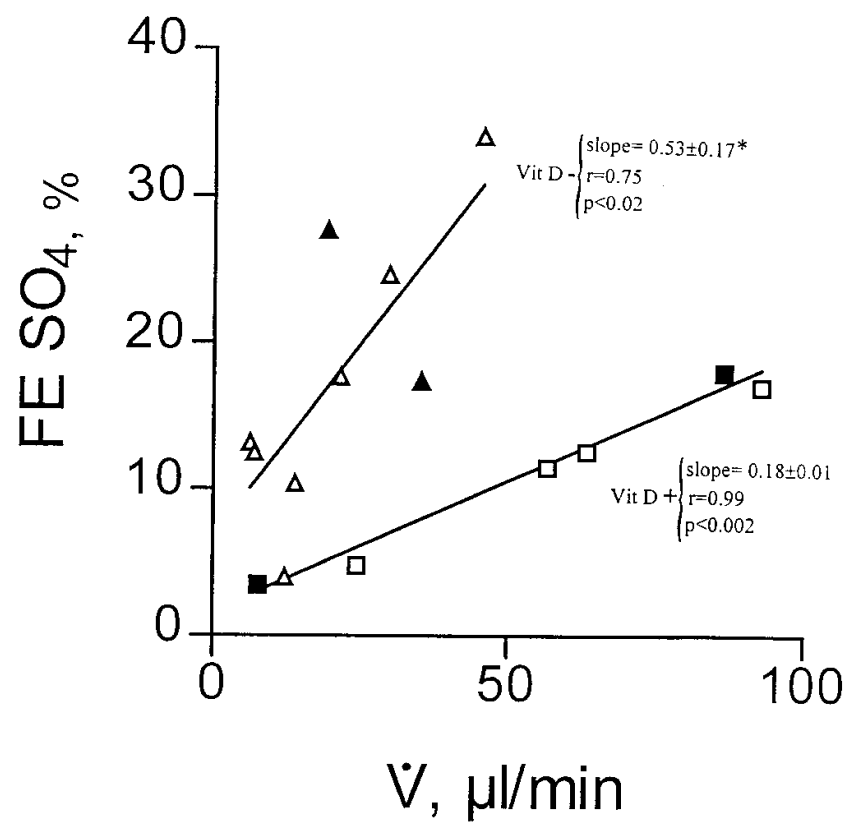

Figure 4. Effect of vitamin D status on sulfate excretion. Fractional excretion of sulfate $\left(\mathrm{FE} \mathrm{SO}_{4}\right)$ and urinary output $(\mathrm{V})$ were measured as described in Methods in nine vitamin D-deficient rats (open triangles, $\mathrm{D}^{-} \mathrm{D}^{-} ;$closed triangles, $\left.\mathrm{D}^{-} \mathrm{Ca}^{+}\right)$and six vitamin $\mathrm{D}-$-supplemented rats (open squares, $\mathrm{D}^{+} \mathrm{D}^{+} ;$closed squares, $\mathrm{D}^{-} \mathrm{D}^{+}$). Results were analyzed by comparing the regression lines obtained for the vitamin D-supplemented and the vitamin-deficient rats. $* P<0.05$ compared with the vitamin D-supplemented group. 
min D-deficient with vitamin D-supplemented rats (Fig. 4). It is noteworthy that the important increase in sulfate excretion contrasted with a modest decrease $(\sim 30 \%)$ of sulfate filtered load, due to the slight decreases of sulfatemia and glomerular filtration rate. Compatible with the lack of effect of calcium/ lactose supplementation on renal $\mathrm{Na}-\mathrm{SO}_{4}$ cotransport mRNA expression, protein abundance and activity, fractional sulfate excretion was not different comparing vitamin D-deficient animals that did or did not receive calcium/lactose supplementation (Fig. 4).

\section{Discussion}

Inorganic sulfate is essential for a variety of metabolic processes, and sulfate requirements in man and other mammalian species appear to change as a function of growth and age (3436). Thus, mechanisms permitting the regulation of plasma sulfate levels are likely to be important for normal physiology, and abnormalities in these processes may contribute to the pathogenesis of various diseases. This study demonstrates for the first time that the expression and activity of the recently cloned renal sodium-sulfate cotransporter, renal sulfate handling, and serum sulfate concentrations are concomitantly regulated by vitamin D status.

Plasma sulfate levels, renal $\mathrm{Na}-\mathrm{SO}_{4}$ cotransport expression, and renal sulfate handling were evaluated in vitamin D-deficient rats and in vitamin D-deficient animals rendered normocalcemic by either vitamin D or calcium/lactose supplementation. Vitamin D-deficient rats developed hyposulfatemia and decreased renal Na-SO $\mathrm{S}_{4}$ cotransport activity measured in $\mathrm{BBM}$ vesicles. This decrease in renal Na-SO $\mathrm{S}_{4}$ cotransport activity resulted from a decrease in the $V_{\max }$ of the transport system, and was accompanied by parallel decreases in both $\mathrm{Na}-\mathrm{SO}_{4}$ cotransport protein and mRNA content. Furthermore, it was associated with an increase in the fractional excretion of sulfate, strongly suggesting that the changes in $\mathrm{Na}_{-} \mathrm{SO}_{4}$ cotransporter activity directly influence renal sulfate excretion, and thereby contribute to the observed changes in plasma sulfate. It is noteworthy that the decrease in plasma sulfate was more moderate than might have been anticipated from the large increase in urinary sulfate excretion observed in vitamin D-depleted animals. These findings suggest that additional changes are occurring that partially compensate for the increased renal sulfate excretion in vitamin D-deficient animals. Modulation of intestinal absorption of sulfate could participate. Intestinal sulfate absorption depends, at least in part, on sodium-dependent transport, and the intestinal $\mathrm{Na}-\mathrm{SO}_{4}$ cotransporter is known to be the same as that expressed in the kidney $(12,13)$. Whether vitamin $\mathrm{D}$ status also regulates the intestinal $\mathrm{Na}-\mathrm{SO}_{4}$ cotransporter remains to be determined. It is also possible that vitamin D deficiency results in increased sulfate release from bone. In this regard, no information is available concerning the regulation by vitamin $\mathrm{D}$ of the sulfate transport protein DTDST expressed in bone (4). Clearly, definition of the relative contribution of renal sulfate excretion, intestinal absorption, and release from bone in modulating serum sulfate in vitamin D deficiency will require further study.

Vitamin D supplementation resulted in a return of both renal cortical $\mathrm{Na}-\mathrm{SO}_{4}$ cotransport mRNA and protein to normal levels, changes that were associated with a normalization of fractional sulfate excretion and correction of the hyposulfatemia. Prior studies have indicated that sex, menstrual cycle, pregnancy, and thyroid hormone can influence plasma $\mathrm{SO}_{4}$ levels (1), but the mechanisms involved have not been defined. Regulation of renal $\mathrm{BBM} \mathrm{Na}-\mathrm{SO}_{4}$ cotransport activity by glucocorticoids (37) and thyroid hormone has also been reported (38), although the latter finding was not confirmed in all studies (39). In neither case, however, were changes in $\mathrm{Na}-\mathrm{SO}_{4}$ cotransport activity demonstrated to produce changes in renal sulfate handling or serum sulfate levels. In addition, changes in $\mathrm{Na}-\mathrm{SO}_{4}$ cotransport activity have not been shown previously to result from regulation of the expression of $\mathrm{Na}-\mathrm{SO}_{4}$ cotransport protein or mRNA, as demonstrated in this study.

Renal Na-SO $\mathrm{S}_{4}$ cotransport activity, protein abundance, and mRNA levels remained decreased, and fractional excretion of sulfate remained increased in vitamin D-deficient rats that received calcium/lactose supplementation. These rats had normal plasma calcium concentrations, but lower $1,25(\mathrm{OH})_{2} \mathrm{D}$ levels than the rats that had received vitamin $\mathrm{D}$ supplementation $\left(\mathrm{D}^{+} \mathrm{D}^{+}\right.$and $\mathrm{D}^{-} \mathrm{D}^{+}$groups). Because hypocalcemia and elevated $\mathrm{PTH}$ levels were corrected in animals receiving either vitamin D supplements or lactose and calcium, whereas renal $\mathrm{Na}-\mathrm{SO}_{4}$ cotransport was corrected only by vitamin $\mathrm{D}$ supplementation, these results indicate that it is the vitamin $\mathrm{D}$ status, most likely the active metabolite $1,25(\mathrm{OH})_{2} \mathrm{D}$, not plasma calcium or PTH levels, that regulates the expression and activity of the renal Na-SO ${ }_{4}$ cotransporter in this model. Similarly, several findings indicate that plasma phosphate is unlikely to be implicated in the regulation of renal $\mathrm{Na}-\mathrm{SO}_{4}$ cotransport expression and activity in our model. First, the two vitamin D-deficient groups ( $\mathrm{D}^{-} \mathrm{D}^{-}$and $\mathrm{D}^{-} \mathrm{Ca}^{+}$groups) had significantly different plasma phosphate levels but similar $\mathrm{Na}-\mathrm{SO}_{4}$ cotransport expression and activity. Conversely, vitamin D-deficient animals that did $\left(\mathrm{D}^{-} \mathrm{D}^{+}\right.$group) or did not receive vitamin $\mathrm{D}$ supplementation $\left(\mathrm{D}^{-} \mathrm{D}^{-}\right.$group) had similar phosphate levels, but significantly different levels of expression of renal Na-SO $\mathrm{S}_{4}$ cotransport mRNA and protein.

Interestingly, sulfatemia was normal in vitamin D-deficient animals receiving lactose and calcium, despite that renal $\mathrm{Na}-$ $\mathrm{SO}_{4}$ cotransport activity and expression remained decreased and fractional sulfate excretion remained increased in these animals. This implies that the renal transport of sulfate is still compromised in this group of animals as a consequence of the persistent vitamin $\mathrm{D}$ deficiency. These findings also indicate the restoration of plasma sulfate must have resulted from changes independent of renal sulfate transport, such as increased intestinal absorption of sulfate. As discussed above, changes in the activity of the intestinal $\mathrm{Na}-\mathrm{SO}_{4}$ cotransporter could potentially contribute to the regulation of serum sulfate. Alternatively, increased intestinal absorption of sulfate could occur in this group of rats by a mechanism independent of $\mathrm{Na}_{-} \mathrm{SO}_{4}$ cotransport activity. In this regard, a lactose-induced enhancement of the passive (or diffusional) component of calcium transport has been suggested to explain the ability of lactose to increase intestinal calcium absorption $(15,16)$. An analogous mechanism might be responsible for increasing intestinal sulfate uptake, thereby increasing serum sulfate concentrations.

A deficit in sulfate occurring in vitamin D deficiency may have important clinical implications. Proteoglycans are extremely important for the maintenance of the normal structure and function of bone and cartilage. Sulfation of all naturally occurring sulfated compounds, including proteoglycans, depends on the availability of inorganic sulfate, which is the pre- 
cursor of $3^{\prime}$-phosphoadenosine $5^{\prime}$-phosphosulfate (PAPS), the activated form of sulfate (40). Recently, several inherited forms of osteochondrodysplasia have been shown to result from abnormalities in sulfate transport or metabolism (4-6). A limitation in the availability of inorganic $\mathrm{SO}_{4}$ produced by an acquired defect may also result in abnormal sulfation of proteoglycans. Altered proteoglycan synthesis by aortic endothelial cells (41) and epiphyseal cartilage (42) maintained in vitro in medium containing low sulfate concentrations has been observed. Thus, by regulating renal sulfate transport and sulfatemia, vitamin D status would appear to be a major factor influencing the amount of inorganic sulfate available for sulfation of proteoglycans.

In conclusion, these results demonstrate that vitamin $\mathrm{D}$ status modulates renal Na- $\mathrm{SO}_{4}$ sulfate cotransport and sulfate homeostasis, and thereby influences the amount of inorganic sulfate available for sulfation of proteoglycans. Therefore, vitamin $\mathrm{D}$ deficiency may result in a defect in the synthesis of these important matrix components, a mechanism that may contribute to producing some of the abnormalities observed in rickets and osteomalacia. As it has been demonstrated by in vitro studies that PTH can directly stimulate the sulfation of proteoglycans (43), the regulation of sulfate metabolism, like that of calcium and phosphate, appears to be subject to coordinate regulation by both PTH and vitamin D.

\section{Acknowledgments}

G. Hampson was the recipient of a fellowship from the Medical Research Council (UK), the Centre National de la Recherche Scientifique (France), and the Fondation pour la Recherche Medicale (France).

\section{References}

1. Tallgren, L.G. 1980. Inorganic sulphates in relation to the serum thyroxine level and in renal failure. Acta Med. Scand. Suppl. 640:1-100.

2. Gehron Robey, P., L.W. Fisher, M.F. Young, and J.D. Termine. 1988. The biochemistry of bone. In Osteoporosis: Etiology, Diagnosis, and Management. B.L. Riggs and L.J. Melton III, editors. Raven Press, New York. 95-109.

3. Boskey, A.L. 1989. Noncollagenous matrix proteins and their role in mineralization. Bone Miner. 6:111-123.

4. Hastbacka, J., A. de la Chapelle, M.M. Mahtani, G. Clines, M.P. ReeveDali, M. Daly, B.A. Hamilaton, K. Kusumi, B. Trivedi, A. Weaver, et al. 1994. The diastrophic dysplasia gene encodes a novel sulfate transporter: positional cloning by fine-structure linkage disequilibrium mapping. Cell. 78:1073-1087.

5. Superti-Furga, A. 1994. A defect in the metabolic activation of sulfate in a patient with achondrogenesis type IB. Am. J. Hum. Genet. 55:1137-1145.

6. Hastbacka, J., A. Superti-Furga, W.R. Wilcox, D.L. Rimoin, D.H. Cohn, and E.S. Lander. 1996. Atelosteogenesis type II is caused by mutations in the diastrophic dysplasia sulfate-transporter gene (DTDST): evidence for a phenotypic series involving three chondrodysplasias. Am. J. Hum. Genet. 58:255-262.

7. Sugahara, K., and N.B. Schwartz. 1979. Defect in $3^{\prime}$-phosphoadenosine 5 '-phosphosulfate formation in brachymorphic mice. Proc. Natl. Acad. Sci. USA. 76:6615-6618.

8. Aurbach, G.D., S.J. Marx, and A.M. Spiegel. 1992. Metabolic bone disease. In Williams Textbook of Endocrinology. J.D. Wilson and D.W. Foster, editors. Saunders Company, Philadelphia. 1477-1517.

9. Boyan, B.B., V.L. Sylvia, D.D. Dean, and Z. Schwartz. 1994. Nongenomic effects of vitamin D. In Vitamin D, a Pluripotent Steroid Hormone. Structural Studies, Molecular Endocrinology and Clinical Applications. A.W. Norman, R. Bouillon, and M. Thomasset, editors. W. de Gruyter, New York. 334-340

10. Pita, J.C., L.A. Cuervo, J.E. Madruga, F.J. Muller, and D.S. Howell. 1970. Evidence for a role of protein polysaccharides in regulation of mineral. Phase separation in calcifying cartilage. J. Clin. Invest. 49:2188-2193.

11. Mankin, H.J., and L. Lipiello. 1969. Nucleic acid and protein synthesis in epiphyseal plates of rachitic rats. Bone Joint Surg. 51A:862-874.

12. Murer, H., D. Markovitch, and J. Biber. 1994. Renal and small intestinal sodium-dependent symporters of phosphate and sulphate. J. Exp. Biol. 196: $167-181$.
13. Markovitch, D., M. Bissig, V. Sorribas, B. Hagenbuch, P.J. Meier, and H. Murer. 1994. Expression of rat renal sulfate transport systems in Xenopus laevis oocytes. Functional characterization and molecular identification. J. Biol. Chem. 269:3022-3026.

14. Turner, G., C. Coureau, M. Riszk Rabin, B. Escoubet, M. Hruby, O. Walrant, and C. Silve. 1995. Parathyroid hormone (PTH)/PTH-related protein receptor messenger ribonucleic acid expression and PTH response in a rat model of secondary hyperparathyroidism associated with vitamin D deficiency. Endocrinology. 136:3751-3758.

15. Au, W.Y.W., and G. Raisz. 1967. Restoration of parathyroid responsiveness in vitamin $\mathrm{D}$-deficient rats by parenteral calcium or dietary lactose. $J$. Clin. Invest. 46:1572-1578.

16. Kollenkirchen, U., J. Fox, and M.R. Walters. 1991. Normocalcemia without hyperparathyroidism in vitamin D-deficient rats. J. Bone Miner. Res. 6: 273-278.

17. Morin, P., C. François, and M. Dreux. 1994. Séparation de cations et anions inorganiques par électrophorèse capillaire ionique avec une détection spectrométrique UV indirecte. Analusis. 22:178-187.

18. François, C., P. Morin, and M. Dreux. 1995. Effect of the concentration of 18-crown- 6 added to the electrolyte upon the separation of ammonium, alkali and alkaline earth cations by capillary electrophoresis. J. Chromatogr. 706: 535-553.

19. François, C., P. Morin, and M. Dreux. 1995. Separation of transition metal cations by capillary electrophoresis. Optimization of complexing agent concentrations (lactic acid and 18-crown-6). J. Chromatogr. 717:393-408.

20. François, C., P. Morin, and M. Dreux. 1996. Adjusting the selectivity of inorganic anion separation by capillary electrophoresis. J. High Resolut. Chromatogr. 19:5-16.

21. Biber, J., B. Stieger, W. Hasase, and H. Murer. 1981. A high yield preparation for rat kidney brush border membranes. Different behaviour of lysosomal markers. Biochem. Biophys. Acta. 647:169-176.

22. Bradford, M.M. 1976. A rapid and sensitive method for the quantitation of microgram quantities of protein utilizing the principle of protein-dose binding. Anal. Biochem. 72:248-254.

23. Lötscher, M., M. Custer, E.S. Quabius, B. Kaissling, H. Murer, and J. Biber. 1996. Immunolocalization of $\mathrm{Na} / \mathrm{SO}_{4}$ cotransport (Na-Si-1) in rat kidney. Pflügers Arch. 432:373-378.

24. Custer, M., H. Murer, and J. Biber. 1994. Nephron localization of Na/ $\mathrm{SO}_{4}{ }^{2-}$ cotransport-related mRNA and protein. Pflügers Arch. 429:165-168.

25. Laemmli, U.K. 1970. Cleavage of structural proteins during the assembly of the head of bacteriophage $\mathrm{T}_{4}$. Nature (Lond.). 227:680-685.

26. Schneider, E.G., J.C. Durham, and B. Sacktor. 1984. Sodium-dependent transport of inorganic sulfate by rabbit renal brush-border membrane vesicles. Effects of other ions. J. Biol. Chem. 259:14591-14599.

27. Herak-Kramberger, C.M., B. Spindler, J. Biber, H. Murer, and I. Sabolié. 1996. Renal type II Na/Pi-cotransporter is strongly impaired whereas the $\mathrm{Na}$ /sulphate-cotransporter and aquaporin 1 are unchanged in cadmium-treated rats. Pflügers Arch. Eur. J. Physiol. 432:336-344.

28. Pritchard, J.B., and J.L. Renfro. 1983. Renal sulfate transport at the basolateral membrane is mediated by anion exchange. Proc. Natl. Acad. Sci. USA 80:2603-2607.

29. Friedlander, G., S. Couette, C. Coureau, and C. Amiel. 1992. Mechanisms whereby extracellular adenosine $3^{\prime}, 5^{\prime}$-monophosphate inhibits phosphate transport in cultured opossum kidney cells and in rat kidney. J. Clin. Invest. $90: 848-858$.

30. Amiel, C., H. Kuntziger, S. Couette, C. Coureau, and N. Bergounioux 1976. Evidence for a parathyroid hormone-independent calcium modulation of phosphate transport along the nephron. J. Clin. Invest. 57:256-263.

31. Snedecor, G.W., and W.G. Cochran. 1972. Statistical Methods. Iowa State University Press, Ames. 593 pp.

32. Magagnin, S., A. Werner, D. Markovich, V. Sorribas, G. Stange, J. Biber, and H. Murer. 1993. Expression cloning of human and rat renal cortex Na/Pi cotransport. Proc. Natl. Acad. Sci. USA. 90:5979-5983.

33. Kilav, R., J. Silver, J. Biber, H. Murer, and T. Naveh-Many. 1995. Coordinate regulation of rat renal parathyroid hormone receptor mRNA and $\mathrm{Na}-\mathrm{Pi}$ cotransporter mRNA and protein. Am. J. Physiol. 268:F1017-F1022.

34. Neiberger, R.E. 1992. Developmental changes in the renal capacity for sulfate reabsorption in the guinea pig. Pediatr. Nephrol. 6:65-67.

35. Pena, D.R., and R.E. Neiberger. 1992. Developmental differences in renal sulfate reabsorption: transport kinetics in brush border membrane vesicles. Pediatr. Nephrol. 6:532-535.

36. Bakhtian, S., R.E. Kimura, and R.E. Galinsky. 1993. Age-related changes in homeostasis of inorganic sulfate in male F-344 rats. Mech. Ageing Dev. 66:257-267.

37. Renfro, J.L., N.B. Clark, R.E. Metts, and M.A. Lynch. 1989. Glucocorticoid inhibition of $\mathrm{Na}_{-} \mathrm{SO}_{4}$ transport by chick renal brush-border membranes. Am. J. Physiol. 256 (Regulatory Integrative Comp. Physiol. 25):1176R-1183R.

38. Tenenhouse, H.S., J. Lee, and N. Harvey. 1991. Renal brush-border membrane $\mathrm{Na}^{+}$-sulfate cotransport: stimulation by thyroid hormone. Am. J. Physiol. 261 (Renal Fluid Electrolyte Physiol. 30):420F-426F.

39. Beers, K.W., and T.P. Dousa. 1993. Thyroid hormone stimulates the $\mathrm{Na}^{+}-\mathrm{PO}_{4}$ symporter but not the $\mathrm{Na}^{+}-\mathrm{SO}_{4}$ symporter in renal brush border. $\mathrm{Am}$. 
J. Physiol. 265 (Renal Fluid Electrolyte Physiol. 34):323F-326F. 40. White, A., P. Handler, and E.L. Smith. 1968. Principles of Biochemistry. McGraw-Hill, New York. 1187 pp.

41. Humphries, D.E., C.K. Silbert, and J.E. Silbert. 1986. Glycosaminoglycan production by bovine aortic endothelial cells cultured in sulfate-depleted medium. J. Biol. Chem. 261:9122-9127.

42. Ito, K., K. Kimata, M. Sobue, and S. Suzuki. 1982. Altered proteoglycan synthesis by epiphyseal cartilage in culture at low $\mathrm{SO}_{4}{ }^{2-}$ concentration. J. Biol. Chem. 257:917-923.

43. Koike, T., M. Iwamoto, A. Shimazu, K. Nakashima, F. Suzuki, and Y. Kato. 1990. Potent mitogenic effects of parathyroid hormone (PTH) on embryonic chick and rabbit chondrocytes. Differential effects of age on growth, proteoglycan, and cyclic AMP responses of chondrocytes to PTH. J. Clin. Invest. $85: 626-631$. 